\title{
Community Managed Forest Groups and Preferences for REDD+ Contract Attributes: A Choice Experiment Survey of Communities in Nepal
}

\author{
Saban T.M. Dissanayake ${ }^{1}$, Prakash Jha ${ }^{2}$, Bhim Adbikari ${ }^{3}$, Rajesh Bista ${ }^{4}$, Randall \\ Bluffstone ${ }^{5}$, Harisharan Luintel ${ }^{6}$, Peter Martinsson ${ }^{7}$, Naya Sharma Paudel ${ }^{8}$, Eswaran \\ Somanathan ${ }^{9}$ and Michael Toman ${ }^{10}$ \\ ${ }^{1}$ Colby College and Portland State University-USA, ${ }^{2}$ University of Venice Ca Foscari-Italy and ForestAction-Nepal, ${ }^{3}$ IDRC-Canada, ${ }^{4}$ \\ ${ }^{8}$ ForestAction-Nepal, ${ }^{5}$ Portland State University-USA, ${ }^{6}$ Portland State University-USA and ForestAction-Nepal, \\ ${ }^{7}$ University of Gothenburg-Sweden, ${ }^{9}$ Indian Statistical Institute-India, ${ }^{10}$ The World Bank-Washington DC \\ Corresponding author: sdissan2@gmail.com
}

\begin{abstract}
A significant portion of the world's forests that are eligible for Reducing Emission from Deforestation and Forest Degradation (REDD+) payments are community managed forests. At the same time, there is a little knowledge in the existing literature about the preferences of households in the communities with community managed forests for REDD+ contracts. We use a choice experiment survey of rural communities in Nepal to understand the respondent's preferences towards the institutional structure of REDD+ contracts. We split our sample across the communities with community managed forests groups and those without to see how the prior involvement in community managed forest groups' impact preferences. Results show that respondents care about how the payments are divided between the households and the communities, the restrictions on firewood use, the restrictions on grazing and the level of payments. Finally we use a series of demographic interactions terms to analyze how the institutional arrangements and beliefs about climate change and benefits from the REDD+ program influence respondents' beliefs. We find that there are no significant differences in the preferences for the REDD+ contract attributes between the Community Forests (CF) and non-CF respondent groups but we find that respondent groups differ in their beliefs about REDD+ payments and the institutional arrangements.
\end{abstract}

Key words: REDD+, community forestry, Nepal, choice experiment, interaction terms

\section{INTRODUCTION}

The objective of the paper is to inform policy dialogue in the areas of Reducing Emission from Deforestation and Forest Degradation, conservation and sustainable management of forest, and enhancement of carbon $(\mathrm{REDD}+)$ in the context of community based forest management (CBFM). REDD+ is a payment for ecosystem services (PES) system created under the United Nation's Framework Convention on Climate Change (UNFCCC) that tries to reduce deforestation and forest degradation in tropical developing countries not subject to require emission reduction under the convention (non-Annex 1 countries). The ' + ' in REDD+ stands for other co-benefits (e.g. conserve, manage, and enhance forest carbon sustainably) that have been added to the original REDD program (that was focused solely on carbon) to expand the area of contribution that forest can make to mitigate climate change.

REDD+ is important because the loss of forest biomass through deforestation and forest degradation accounts for 12-20 per cent of annual greenhouse gas emissions (Saatchi et al. 2011; van der Werf et al. 2009; UNEP 2012). Due to the increasing ${ }^{1}$ trend of the decentralization of forest management under CBFM in Nepal and elsewhere, the success of REDD+ would depend on how CBFM would be included in the REDD+ program (World Bank 2009; Agrawal et al. 2008).

The effectiveness and decision to adopt REDD+ in CBFM depends on incentives, benefit sharing arrangements, the opportunity

${ }^{1}$ The forest decentralization is rapidly increasing over time and therefore the area of community forests roughly doubled to 250 million hectares during the period 1997-2008 (World Bank 2009). 
costs of carbon sequestration, allocation of forest management decision making rights, and community interactions (McKinsey and Co. 2010; Gregorsen et al. 2011) but there is a lack of a clear picture on the opportunity costs in case of the CBFM. For example, some say REDD+ is a cheaper mitigation option (Angelsen 2008; McKinsey and Co. 2010; Kindermann et al. 2008; Strassburg et al. 2009); while others find REDD+ as costly (Dyer and Counsel 2010; Gregorsenet et al. 2011; Yesuf and Bluffstone 2009).

In this paper, we use choice experiment (CE) survey in rural Nepali communities to understand people's preference towards the structure of REDD+ contracts and the opportunity costs they face. We choose Nepali Community Forests (CFs) ${ }^{2}$ for the study because of its long history, and larger forest areas and population under CFs management.We include respondents from both communities that are part of the CFs and communities that do not have CFs to gain an understanding of how being a member of the CFs will influence the preference to adopt REDD+ contracts.

Results from the survey show that respondents care about how REDD+ programs are structured with regard to the manner in which the payments are divided between the households and the communities, the restrictions on using grazing land, firewood collections, and the level of payments received for the program. We find that the respondents prefer that more of the REDD+ payments should go to the communities rather than households, which indicate trust in the community level institutions. We also find that the CF and non-CF communities differ in their beliefs about the institutional structure.
In general, ensuring equitable access to forest resources, proper monitoring of forest use and also preventing corruption can result in contracts being adopted for lower payments.

\section{REDD+ in Nepal}

Nepal became interested in REDD+ and submitted the Readiness Program Idea Note (RPIN) to the Forest Carbon Partnership Facility (FCPF) of the World Bank for getting assistance in REDD+ related preparedness development (MFSC 2008). Nepal's RPIN was accepted in 2008 and got financial assistance from the FCPF to develop Readiness Preparation Proposal (RPP) (MFSC 2010). At the central level, REDD+ structures (e.g., REDD Apex body, REDD working group and REDD cell) have been formed to support the readiness process which is implementing World Bank's FCPF supported activities including the RPP since 2010. Similarly, there are several non-state organizations working on the diverse aspects of REDD+ readiness activities including building capacity of stakeholders (Luintel et al. 2013), developing methodologies for biomass assessment, designing institutional mechanisms for equitable benefit sharing, and developing social and environmental safeguards to protect rights of local and indigenous communities.

While the additional benefits from REDD+ is expected to get peoples' support in conservation, there might be additional costs which can potentially produce trade-offs with the expected benefits. Some of these costs include sacrifices to reducing the amount of fuelwood consumption, reduce the amount and frequency of grazing, and increase cost for forest protection activities. In this paper, we analyze these costs and the preferences for REDD+ contracts.

\footnotetext{
${ }^{2} \mathrm{CFs}$ in Nepal are patches of national forest area handed over to the local user group for management, conservation and utilization according to the Forest Act 1993 and subsequent Forest Regulation 1995 (HMGN 1993; HMGN 1995). CF policy in Nepal emerged after an urgent need to stop forest degradation in Nepalese Himalayas (Ives and Messerli 1989) and failure of the government approach to protect forests (Kanel 2004a). Until 2014 January, there are 18,133 forest user groups, managing 1.7 million hectares of forest area (DOF 2014). Gradually, CFs developed as an institution not only implementing forest management activities but also various community development activities and improving rural livelihoods (Kanel 2004b; Luintel et al. 2009).
} 
METHODOLOGY

Choice Experiment Surveys

We use CE surveys for this study because we are interested in understanding how the different characteristics of the REDD+ contracts influence adoption of contracts. CE surveys allow us to calculate trade-offs between attributes and the marginal value of each attribute. They are based on the Lancaster's (1966) consumer theory and are used to elicit preferences for environmental goods and policies (Boxall et al. 1996; Louviere et al. 2000). In a typical CE survey, the respondent repeatedly chooses the best bundle/choice from several hypothetical bundles/choices. The attribute values appearing in each bundle/ choice are identified using experimental design techniques to ensure a balanced representation of values across choices. Hanley et al. (2001), Hensher et al. (2005) and Hoyos (2010) provide reviews of the choice experiment methodology.

\section{Survey Instruments and Experimental Design}

The survey for this study presents respondents with opportunities to express preferences over hypothetical REDD+ contracts. The attributes of costs and benefits and their levels, presented in Table 1, were selected through the focus group discussions in nine CFs and the same number of non-CFs. These CFs were selected from hill and Terai regions on purpose. In each region, the CFs were selected from the random set of sites from a previous CF impact study (MFSC 2013). The surveys given out to communities that are non-CF had four attributes (e.g., fire wood collection, payment to community, payment level, and grazing); while communities with CFs do not contain grazing restriction attributes because they already have grazing restrictions in place. The exact list of attributes was refined after studying the REDD+ literature and analyzing results from focus groups in multiple communities.

Table 1: Attributes and Levels for the REDD+ Survey Instrument

\begin{tabular}{lll}
\hline Attributes & & Levels \\
\hline REDD + payments & Annual total REDD+ payment to & 1000 \\
$\begin{array}{l}\text { Nepalese Rupees - NRs. per } \\
\text { household per year) }\end{array}$ & your community. & 2000 \\
& & 3000 \\
& & 4000 \\
& & 5000 \\
\hline Portion of the REDD+ & The portion of REDD+ payments & 100 per cent community \\
payment going to the & that go to communities for & 50 per cent community and \\
household. & community projects and/or equally & 50 per cent household \\
& divided between households in your & 100 per cent household \\
& group. & \\
\hline Reduction in amount of fuel & Required fuelwood reduction & 25 per cent \\
wood collected & measured as a portion of your & 50 per cent \\
& current use. & 75 per cent \\
& & 100 per cent \\
\hline Grazing restrictions & Required reduction of grazing & Yes \\
& measured as a portion of your & No \\
& current use. & \\
\hline
\end{tabular}


Once an initial list of attributes was developed, we conducted focus groups with potential survey respondents. The final survey instrument contained background information about the REDD+ program, description of the attributes and the levels, seven sets of choice questions, and a detailed demographic questionnaire. These documents were pretested in the field before launching full implementation. For each choice question, the respondents chose between the two REDD+ alternatives and astatus quo option.

We followed standard practice in the choice modeling literature (Adamowicz et al. 1997; Adamowicz et al. 1998; Louviere et al. 2000) and created an efficient experiment design that allows both main effects and interaction effects to be estimated. The designs for the choice experiments were generated following Kuhfeld (2010) ${ }^{3}$ and achieved a 100 per cent D-efficiency. ${ }^{4}$

\section{Model and Estimation}

We used a mixed Multinomial Logit Model $(\mathrm{MMNL})^{5}$ that incorporates heterogeneity of preferences (Carlsson et al. 2003; Hensher and Greene 2003; Train 2003; Hensher et al. 2005; and Dissanayake 2014) as the respondents might not be homogenous. See Dissanayake (2014) for a derivation of the MMNL model.

We present main effects (no interactions) specification and specifications with attribute and regional interaction terms. The specifications are given in Equation (1)Equation (2):

$$
\begin{aligned}
V_{n i}= & \beta_{1 n} X_{\text {payment to community }}+\beta_{2 n} X_{\text {firewood }} \\
& +\beta_{3 n} X_{\text {grazing }}+\beta_{4 n} X_{\text {payment }}+\varepsilon_{n i} \\
V_{n i}= & (6)+\beta_{s n} A S C * Z_{s}
\end{aligned}
$$

where $Z$ s denotes the socio-demographic variables. The data were analyzed using the clogit and mixlogit commands in STATA for the Conditional Logit and MMNL specifications.

\section{Data}

Data were collected using a split sample equally weighted between communities with $\mathrm{CBFM}$ and communities without CBFM. The location of the sites is shown in Figure 1. The sampling design for CBFMs was adopted from the data set of the CBFM impact study (MFSC 2013). For each community with CBFM, the matching communities not having CBFM were selected based on criteria such as the socio-economic characteristics, forest types and accessibility. Data were collected from 1300 randomly selected households in both the hill and plains (Terai) in Nepal. Out of the 1300 selected households, 650 were from 65 communities that currently have CBFMs and the other 650 households from 65 communities that currently do not have CBFMs.

\footnotetext{
${ }^{3}$ The experiment design was conducted using the SAS experiment design macro (Kuhfeld 2010).

${ }^{4} \mathrm{D}$-efficiency is the most common criterion for evaluating linear designs. D-efficiency minimizes the generalized variance of the parameter estimates given by $\mathrm{D}=\operatorname{det}[\mathrm{V}(\mathrm{X}, \beta) 1 / \mathrm{k}]$ where $\mathrm{V}(\mathrm{X}, \beta)$ is the variance-covariance matrix and $\mathrm{k}$ is the number of parameters. Huber and Zwerina (1996) identified four criteria (orthogonality, level balance, minimum overlap, and utility balance) which are required for a D-efficient experiment design.

${ }^{5}$ This approach is also referred to as the mixed, hybrid, random parameter, and random coefficient logit model.
} 


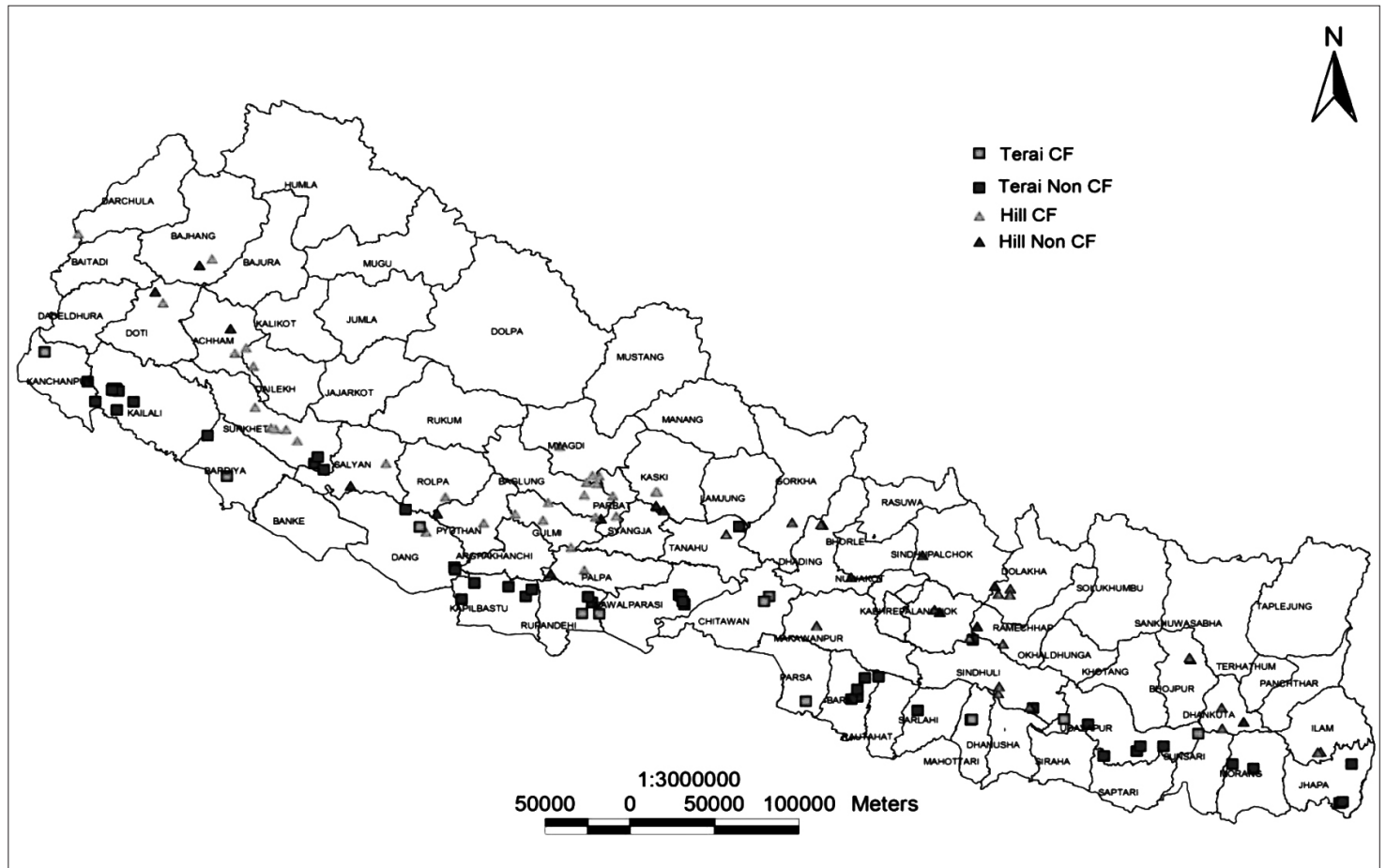

Figure 1: Map of Nepal Showing Research Sites

\section{Household characteristics}

A summary of the household characteristics is provided in Table 2 for both CF and non$\mathrm{CF}$ households. On average, the CF and non$\mathrm{CF}$ households were very similar. For the $\mathrm{CF}$ households, 81.2 per cent of the respondents were male, 38.9 per cent were categorized as "poor" and 52 per cent categorized as "medium" with regards to the social status. For the non-CF households, 86.3 per cent of the respondents were male, 37.5 per cent were categorized as "poor" and 51.4 per cent categorized as "medium" with regards to social status. Both groups were similar in educational achievements; for CF households, 21.6 per cent was illiterate, 33.8 per cent only had a primary education, and 17.3 per cent didn't have secondary school education whereas 11.4 per cent finished secondary school. For CF households, 20.4 per cent was illiterate, 37.1 per cent had primary education, and 16.2 per cent didn't have secondary school education whereas 11.4 per cent finished secondary school education. 
Table 2: Household Characteristics in CFs and Non-CFs

\begin{tabular}{|c|c|c|c|c|}
\hline SN & Variable & $\begin{array}{l}\text { CF } \mathrm{HH} \\
\text { per cent }\end{array}$ & $\begin{array}{l}\text { Non-CF HH } \\
\text { per cent }\end{array}$ & p-value \\
\hline A & Gender & & & \\
\hline 1 & Women headed households (WHH) & 18.77 & 13.69 & 0.01306 \\
\hline 2 & WHH due to temporary migration of men & 4.15 & 3.69 & 0.6682 \\
\hline 3 & WHH due to men's death & 6.77 & 4.92 & 0.156 \\
\hline B & Wellbeing class & & & \\
\hline 1 & Rich & 9.08 & 11.08 & 0.231 \\
\hline 2 & Medium & 52 & 51.38 & 0.8243 \\
\hline 3 & Poor & 38.92 & 37.54 & 0.6075 \\
\hline C & Caste groups & & & \\
\hline 1 & Dalit & 14.46 & 17.69 & 0.1128 \\
\hline 2 & Janajati & 43.69 & 39.38 & 0.1151 \\
\hline 3 & Brahmin/Chhetri & 39.54 & 41.08 & 0.5718 \\
\hline 4 & Others & 2.31 & 1.85 & 0.5596 \\
\hline $\mathbf{D}$ & Age of $\mathrm{HH}$ head (in years) & 52.46 & 48.77 & $4.297 \mathrm{e}-06$ \\
\hline \multirow[t]{4}{*}{$\mathbf{E}$} & Total population & 50.58 & 49.72 & 0.2879 \\
\hline & Men & 51.91 & 52.80 & 0.4315 \\
\hline & Married & 54.24 & 52.20 & 0.07231 \\
\hline & Immigrated & 15.08 & 35.85 & $2.20 \mathrm{E}-16$ \\
\hline $\mathbf{F}$ & Main occupation & & & \\
\hline 1 & Agriculture & 34.48 & 30.80 & 0.0005527 \\
\hline 2 & Skilled worker & 1.26 & 1.69 & 0.1093 \\
\hline 3 & Services in Govt. Organization, NGO, private sector & 3.69 & 3.34 & 0.3984 \\
\hline 4 & Services in foreign country & 7.38 & 6.75 & 0.2804 \\
\hline 5 & Household chores & 6.18 & 7.48 & 0.02278 \\
\hline G & Land holding and food security & & & \\
\hline 1 & Land holding by family & 95.85 & 92.00 & 0.003704 \\
\hline 2 & Food sufficiency from own land & 26.46 & 35.69 & 0.000324 \\
\hline \multirow[t]{4}{*}{$\mathbf{H}$} & $\begin{array}{l}\text { Income fluctuation in last ten years due to agriculture and } \\
\text { livestock }\end{array}$ & & & \\
\hline & Increased & 24.31 & 24.00 & 0.8969 \\
\hline & No change & 57.08 & 60.15 & 0.2601 \\
\hline & Decreased & 18.62 & 15.85 & 0.1862 \\
\hline $\mathbf{I}$ & $\begin{array}{l}\text { Income fluctuation in last ten years due to off-farm } \\
\text { activities }\end{array}$ & & & \\
\hline 1 & Increased & 37.69 & 37.08 & 0.8186 \\
\hline 2 & No change & 53.69 & 54.00 & 0.9114 \\
\hline 3 & Decreased & 8.62 & 8.92 & 0.8445 \\
\hline
\end{tabular}




\section{RESULTS AND DISCUSSIONS}

Given that the choice experiment surveys for the two respondent groups (CF and non$\mathrm{CF}$ ) have different attributes, we analyze the two groups separately and compare the findings. We present four sets of results that correspond to specification (1) and (2). Tables 3 and 4 present results for the main effects specifications analyzed using a conditional logit model (column 1), the main effects specification analyzed using a MMNL model (column 2), and the beliefs and attitude interactions effect specification analyzed using a MMNL (column 3) for the non-CF and CF communities respectively. The significance of the standard deviation estimates for random coefficients from the MMNL is indicated with a "SD" next to the standard errors. ${ }^{6}$ As can be seen in the table, many of the variables exhibit individual heterogeneity and therefore it is necessary to account for this in the analysis by using a MMNL model.

Table 3: Regression Results for the REDD+ CE Survey for Non-CF Communities

\begin{tabular}{|c|c|c|c|}
\hline & $\begin{array}{c}\text { (1) } \\
\text { CL Main Effects }\end{array}$ & $\begin{array}{c}(2) \\
\text { MMNL } \\
\text { Main Effects }\end{array}$ & $\begin{array}{c}(3) \\
\text { MMNL Demographic } \\
\text { Interactions }\end{array}$ \\
\hline ASC & $\begin{array}{l}2.776 * * * \\
(0.102)\end{array}$ & $\begin{array}{l}7.512 * * * \\
(0.526), \mathrm{SD}\end{array}$ & $\begin{array}{l}9.407 * * * \\
(1.688), \mathrm{SD}\end{array}$ \\
\hline Payment per cent to community & $\begin{array}{l}0.0329 * * * \\
(0.00507)\end{array}$ & $\begin{array}{l}0.0733 * * * \\
(0.0153), \mathrm{SD}\end{array}$ & $\begin{array}{l}0.0989 * * * \\
(0.0210), \mathrm{SD}\end{array}$ \\
\hline Firewood reduction & $\begin{array}{l}-0.171 * * * \\
(0.00815)\end{array}$ & $\begin{array}{l}-0.380 * * * \\
(0.0235), \mathrm{SD}\end{array}$ & $\begin{array}{l}-0.299 * * * \\
(0.0266), \mathrm{SD}\end{array}$ \\
\hline Grazing restriction & $\begin{array}{l}-0.299 * * * \\
(0.0360)\end{array}$ & $\begin{array}{l}-0.668 * * * \\
(0.101), \mathrm{SD}\end{array}$ & $\begin{array}{l}0.255^{* *} \\
(0.122), \mathrm{SD}\end{array}$ \\
\hline Payment & $\begin{array}{l}0.141 * * * \\
(0.0159)\end{array}$ & $\begin{array}{l}0.263 * * * \\
(0.0273)\end{array}$ & $\begin{array}{l}-0.296 * * * \\
(0.0357)\end{array}$ \\
\hline $\begin{array}{l}\text { ASC X equitable access to forest } \\
\text { fund }\end{array}$ & & & $\begin{array}{l}-0.919 \\
(0.863)\end{array}$ \\
\hline ASC $\mathrm{X}$ respondent migrated & & & $\begin{array}{l}0.764 \\
(0.866)\end{array}$ \\
\hline ASC X CC serious for Nepal & & & $\begin{array}{l}2.865 * * \\
(1.144)\end{array}$ \\
\hline ASC X CC serious for community & & & $\begin{array}{l}-1.040 \\
(1.030)\end{array}$ \\
\hline ASC X CC serious personally & & & $\begin{array}{l}-0.840 \\
(1.012)\end{array}$ \\
\hline $\begin{array}{l}\text { ASC X REDD+ likely to benefit } \\
\text { community }\end{array}$ & & & $\begin{array}{l}0.988 \\
(0.980)\end{array}$ \\
\hline $\begin{array}{l}\text { ASC X REDD+ likely to benefit } \\
\text { personally }\end{array}$ & & & $\begin{array}{l}-0.215 \\
(1.014)\end{array}$ \\
\hline $\begin{array}{l}\text { ASC X community members } \\
\text { trustworthy }\end{array}$ & & & $\begin{array}{l}0.129 \\
(1.096)\end{array}$ \\
\hline $\begin{array}{l}\text { ASC X community members follow } \\
\text { rules }\end{array}$ & & & $\begin{array}{l}-0.271 \\
(0.821)\end{array}$ \\
\hline
\end{tabular}

${ }^{6}$ Full results tables including the standard deviation estimatesfor the random parameters can be obtained by contacting the corresponding author. 
ASC X rules of access and forest use are clear

$-3.717 * * *$

(1.364)

ASC $\mathrm{X}$ forest access decisions are

fair

1.377

(1.081)

ASC X village authorities monitor $-1.389 *$

ASC X villages monitor forest use

1.162

(0.886)

$1.537 *$

$(0.849)$

breakers

Observations

11694

11694

7122

Log likelihood

$-3027.4$

$-2473.3$

$-1454.8$

Chi-squared

1108.1

581.6 
Table 4: Regression Results for the REDD+ CE Survey for CF Communities

\begin{tabular}{|c|c|c|c|}
\hline & (1) & (2) & (3) \\
\hline & $\begin{array}{l}\text { CL } \\
\text { Main Effects }\end{array}$ & $\begin{array}{l}\text { MMNL } \\
\text { Main Effects }\end{array}$ & $\begin{array}{l}\text { MMNL Demographic } \\
\text { Interactions }\end{array}$ \\
\hline ASC & $\begin{array}{l}3.322 * * * \\
(0.108)\end{array}$ & $\begin{array}{l}7.647 * * * \\
(0.479), \mathrm{SD}\end{array}$ & $\begin{array}{l}\text { 7.179*** } \\
(0.899), \text { SD }\end{array}$ \\
\hline Payment per cent to community & $\begin{array}{l}0.0416 * * * \\
(0.00542)\end{array}$ & $\begin{array}{l}0.0640 * * * \\
(0.0118), \mathrm{SD}\end{array}$ & $\begin{array}{l}0.0590 * * * \\
(0.0121), \mathrm{SD}\end{array}$ \\
\hline Firewood reduction & $\begin{array}{l}-0.260 * * * \\
(0.00913)\end{array}$ & $\begin{array}{l}-0.454 * * * \\
(0.0239), \mathrm{SD}\end{array}$ & $\begin{array}{l}-0.462 * * * \\
(0.0253), \mathrm{SD}\end{array}$ \\
\hline Payment & $\begin{array}{l}0.135 * * * \\
(0.0170)\end{array}$ & $\begin{array}{l}0.255 * * * \\
(0.0250)\end{array}$ & $\begin{array}{l}0.250 * * * \\
(0.0260)\end{array}$ \\
\hline $\begin{array}{l}\text { ASC X equitable access to forest } \\
\text { fund }\end{array}$ & & & $\begin{array}{l}-1.031 * \\
(0.579)\end{array}$ \\
\hline ASC $\mathrm{X}$ respondent migrated & & & $\begin{array}{l}3.029 * * \\
(1.430)\end{array}$ \\
\hline ASC X CC serious for Nepal & & & $\begin{array}{l}1.647 * * \\
(0.800)\end{array}$ \\
\hline ASC X CC serious for community & & & $\begin{array}{l}-2.117 * * \\
(0.824)\end{array}$ \\
\hline ASC X CC serious personally & & & $\begin{array}{l}-0.634 \\
(0.654)\end{array}$ \\
\hline $\begin{array}{l}\text { ASC X REDD+ likely to benefit } \\
\text { community }\end{array}$ & & & $\begin{array}{l}0.349 \\
(0.631)\end{array}$ \\
\hline $\begin{array}{l}\text { ASC X REDD + likely to benefit } \\
\text { personally }\end{array}$ & & & $\begin{array}{l}2.095 * * * \\
(0.681)\end{array}$ \\
\hline $\begin{array}{l}\text { ASC X community members } \\
\text { trustworthy }\end{array}$ & & & $\begin{array}{l}-0.463 \\
(0.798)\end{array}$ \\
\hline $\begin{array}{l}\text { ASC X community members follow } \\
\text { rules }\end{array}$ & & & $\begin{array}{l}-0.591 \\
(0.675)\end{array}$ \\
\hline $\begin{array}{l}\text { ASC X rules of access and forest } \\
\text { use are clear }\end{array}$ & & & $\begin{array}{l}-1.191 \\
(0.816)\end{array}$ \\
\hline $\begin{array}{l}\text { ASC X forest access decisions are } \\
\text { fair }\end{array}$ & & & $\begin{array}{l}1.038 \\
(0.663)\end{array}$ \\
\hline $\begin{array}{l}\text { ASC X village authorities monitor } \\
\text { forest use }\end{array}$ & & & $\begin{array}{l}1.592 * * * \\
(0.545)\end{array}$ \\
\hline ASC X villages monitor forest use & & & $\begin{array}{l}0.516 \\
(0.537)\end{array}$ \\
\hline $\begin{array}{l}\text { ASC X authorities support rule } \\
\text { breakers }\end{array}$ & & & $\begin{array}{l}1.814 * * \\
(0.713)\end{array}$ \\
\hline Observations & 11697 & 11697 & 10851 \\
\hline Log likelihood & -2702.3 & -2316.4 & -2140.5 \\
\hline Chi-squared & 3162.3 & 771.9 & 632.7 \\
\hline
\end{tabular}

Standard errors in parentheses ${ }^{*} p<0.1,{ }^{* *} p<0.05,{ }^{* * *} p<0.01$ 
The overall results from the three specifications indicate that the percentage of the payment going to the community, the required firewood and grazing reduction (for non-CF households) and the payment amount are all significant variables in determining the respondents' willingness to adopt REDD+ contracts. The significant coefficient results are robust across the econometric specifications and have expected signs. The significant results indicate that (i) the respondents are less likely to choose that option as the required firewood reduction and the required grazing reduction increases (in non-CF households); (ii) the respondents are more likely to choose that option as the percentage of the payment to the community increases and as the payment values (amount) increases.

We finally analyze how the institutional arrangements, and beliefs about climate change and the benefits from the REDD+ program influence REDD+ contract adoption decisions. For the CF households to adopt REDD + contracts, we find that respondents who (i) believe they have equitable access to forest funds are willing to accept smaller payments; (ii) are migrants and requires higher payments; (iii) who believe climate change is serious for Nepal require higher payments while respondents that believe climate change is serious for their community require smaller payments; (iv) believe that the REDD+ program will benefit them personally require higher payments; (v) believe village authorities monitor forest use require higher payments; and (vi) believe that authorities support rule breakers require higher payments.

Similarly, for non-CF households to adopt REDD + contracts we find that respondents who (i) believe climate change is serious for Nepal require higher payments; (ii) believe rules of forest access are clear, require smaller payments; (iii) believe village authorities monitor forest use require smaller payments; and (iv) believe that authorities support rule breakers require higher payments.
We find that there are no significant differences in the payment amounts necessary to initiate REDD+ contracts between the CF and non-CF respondent groups but we find that respondent groups differ in their beliefs about REDD+ payments and the institutional arrangements. In general, we find ensuring equitable access to forest resources, preventing corruption and ensuring proper monitoring of forest use can result in contracts being adopted for lower payments.

\section{CONCLUSIONS AND POLICY IMPLICATIONS}

In this paper, we present results from a choice experiment survey conducted in Nepal in 2013 as a part of a collaborative effort to analyze the preference for REDD+ contracts in Nepal. In both $\mathrm{CF}$ and non-CF communities, we find that households prefer higher REDD+ payments and would choose to rather not take on REDD+ obligations without adequate compensation. For example, CF and non$\mathrm{CF}$ respondents generally are not likely to choose options with high levels of firewood reductions and low REDD+ payments. NonCF households also have the option to reduce grazing in exchange for payments. We find that those respondents are less likely to choose options with grazing restrictions than options without such restrictions. Such results are consistent within individuals making choices that are in their own interests.

A key REDD+ policy question here is how to divide up REDD+ payments. Should they entirely go to the communities or to households or partly to households and partly to communities? We find that respondents prefer that more of the payments go to the communities rather than to the households. This result indicates a higher degree of trust in forest user group communities, because their pure self-interest would likely have suggested a preference for payments to go to households where they can be fully controlled. This result 
mirrors our focus group findings. Besides payment levels, good governance and equity are also important in REDD+ contracts.

Finally, we find that people are willing to accept smaller payments if there is an equitable access to forest resources preventing corruption and ensuring proper monitoring of forest use. Overall, our results show that there is a strong willingness to accept REDD+ contracts from community members of both $\mathrm{CF}$ and non-CF communities.

\section{ACKNOWLEDGMENTS}

Financial support for this work was provided by the World Bank Knowledge for Change Program. We would like to thank the participants at the Seminar Series at Reed College and Resources for the Future, and the 2014 World Bank Land and Poverty Conference, for their valuable feedback and suggestions on this work.

\section{REFERENCES}

Adamowicz, W., Boxall, P., Swait, P., Williams, M. and Louviere, J. 1997. Perceptions Versus Objective Measures of Environmental Quality in Combined Revealed and Stated Preference Models of Environmental Valuation. Journal of Environmental Economics and Management, 32: 65-84.

Adamowicz, W., Boxall, P., Williams, M. and Louviere, J. 1998. Stated Preference Approaches for Measuring Passive Use Values: Choice Experiments and Contingent Valuation. American Journal of Agricultural Economics, 80: 64-75.

Agrawal, A., Chhatre, A. and Hardin, R. 2008. Changing Governance of the World's Forests. Science, 320: 1460-1462.

Angelsen, A. (Ed). 2008. Moving Ahead With Reducing Emissions from Deforestation and Forest Degradation (REDD+): Issues, Options and Implications. CIFOR, Bogor, Indonesia.

Boxall, P.C., Adamowicz, W.L., Swait, J., Williams, M. and Louviere, J. 1996. A Comparison of Stated Preference Methods for Environmental Valuation. Ecological Economics, 18: 243-253.

Carlsson, F., Frykblom, P. and Liljenstolpe, C. 2003. Valuing Wetland Attributes: An Application of Choice Experiments. Ecological Economics, 47: 95103.

Dissanayake, S. T. M. 2014. Derivations of the Models to Estimate Discrete Choice Data. Mimeo. (http:// sahan.org/files/working papers/derivations of models to estimate discrete choice data.pdf accessed on 25 January, 2015).

DOF. 2014. Community Forest Database. Kathmandu: Community Forestry Division, Department of Forest.

Dyer, N. and Counsel, S. 2010. McREDD: How McKinsey 'Cost Curves' are Distorting Reducing Emissions from Deforestation and Forest Degradation (REDD+). Policy Brief. Rainforest Foundation UK Climate and Forests.

Gregorsen, H., Lakany, H., Karsenty, A. and White, A. 2011. Does the Opportunity Cost Approach Indicate the Real Cost of Reducing Emissions from Deforestation and Forest Degradation (REDD+)? Rights and Realities of Paying for Reducing Emissions from Deforestation and Forest Degradation (REDD+). Washington D.C: Rights and Resources Initiative.

Hanley, N., Mourato, S. and Wright, R.E. 2001. Choice Modelling Approaches: A Superior Alternative for Environmental Valuation? Journal of Economic Surveys, 15: 435-462.

Hensher, D.A. and Greene, W.H. 2003. The Mixed Logit Model: the State of Practice. Transportation, 30: 133-176.

Hensher, D. A., Rose, J.M. and Greene, W.H. 2005. Applied Choice Analysis: A Primer. Cambridge University Press.

HMGN. 1993. Forest Act 1993. Kathmandu: Ministry of Forest and Soil Conservation, His Majesty's Government of Nepal.

HMGN. 1995. Forest Regulation 1995. Kathmandu: Ministry of Forest and Soil Conservation, His Majesty's Government of Nepal.

Hoyos, D. 2010. The State of the Art of Environmental Valuation With Discrete Choice Experiments. Ecological Economics, 69: 1595-1603.

Huber, J. and Zwerina, K. 1996. The Importance of Utility Balance in Efficient Choice Designs. Journal of Marketing Research, 33: 307-317.

Ives, J. and Messerli, B. 1989. The Himalayan Dilemma, London: Routledge.

Kanel, K.R. 2004a. Current Status of Community Forestry in Nepal. Bangkok: Regional Community Forestry Training Center for Asia and the Pacific (RECOFTC).

Kanel, K. R. 2004b. Twenty Five Years of Community Forestry: Contribution to Millennium Development Goals. In: K. R., Kanel, P. Mathema, B. R. Kandel, D. R. Niraula, A. R. Sharma and M. Gautam (Eds.), Proceeding of Fourth National Community Forestry Workshop. Kathmandu: Community Forestry Division, Department of Forest.

Kindermann, G., Obersteiner, M., Sohngen, B., Sathaye, J., Andrasko, K., Rametsteiner, E., 
Schlamadinger, B., Wunder, S. and Beach, R. 2008. Global Cost Estimates of Reducing Carbon Emissions through Avoided Deforestation. Proceedings of the National Academy of Science, 105: 10302-10307

Kuhfeld, W.F. 2010. Marketing Research Methods in Statistical Analysis System (SAS) Experimental Design, Choice, Conjoint, and Graphical Techniques. North Carolina, USA: SAS Institute Inc. (http://support.sas.com/techsup/technote/ mr2010title.pdf, accessed on 20 February, 2015).

Lancaster, K.J. 1966. A New Approach to Consumer Theory. The Journal of Political Economy, 74: 132157.

Louviere, J.J., Hensher, D.A. and Swait, J.D. 2000. Stated Choice Methods: Analysis and Applications. Cambridge University Press.

Luintel, H., Ojha, H., Rana, B., Subedi, R. and Dhungana, H. 2009. Community Forestry in Nepal: Promoting Livelihoods, Community Development and the Environment. ForestAction and Livelihoods and Forestry Programme.

Luintel, H., Silori, C.S., Frick, S. and Poudyal, B.H. 2013. Grassroots Capacity Building for Reducing Emissions from Deforestation and Forest Degradation (REDD+): Lessons from Nepal. Journal of Forest and Livelibood, 11(2): 1-13.

McKinsey and Co. 2010. Impact of the Financial Crisis on Carbon Economics: Version 2.1 of the Global Greenhouse Gas Abatement Cost Curve. McKinsey and Company. (http://www. mckinsey.com/clientservice/sustainability/pdf/ Impact Financial Crisis Carbon Economics GHGcostcurveV2.1.pdf accessed on 8 January, 2011).

MFSC. 2008. Forest Carbon Partnership Facility Readiness Programme Idea Note (R-PIN) for Reducing Emissions from Deforestation and Forest Degradation (REDD+). Ministry of Forest and Soil Conservation, Government of Nepal.

MFSC. 2010. Nepal's Readiness Preparation Proposal Reducing Emissions from Deforestation and
Forest Degradation (REDD+) 2010-2013. Ministry of Forest and Soil Conservation, Government of Nepal.

MFSC. 2013. Persistence and Change: Review of 30 years of Community Forestry in Nepal. Ministry of Forest and Soil Conservation, Government of Nepal.

Saatchi, S., Harris, M., Brown, S., Lefsky, M., Mitchard, E., Salas, W., Zutta, B., Buermann, W., Lewis, S., Hagen, S., Petrova, S., White, L., Silman, M. and Morel, A. 2011. Benchmark Map of Carbon Forest Carbon Stocks in Tropical Regions across Three Continents. Proceedings of the National Academy of Sciences, 108(24): 9899-9904.

Strassburg, B., Turner, R. K., Fisher, B., Schaeffer, R. and Lovett, A. 2009. Reducing Emissions from Deforestation and Forest Degradation (REDD+) - The "Combined Incentives" Mechanism and Empirical Simulations. Global Environmental Change, 19: $265-278$.

Train, K.E. 2003. Discrete Choice Methods with Simulation. Cambridge University Press.

UNEP. 2012. The Emissions Gap Report 2012: A United Nations Environment Programme (UNEP) Synthesis Report. United Nations Environment Program. (http://www.unep.org/pdf/2012 gapreport.pdf, accessed on 23 January, 2015)

van der Werf, G.R., Morton, D.C., DeFries, R.S., Olivier, J.G.J., Kasibhatla, P.S., Jackson, R.B., Collatz, G.J. and Randerson, J.T. 2009. CO2 Emissions From Forest Loss. Nature Geoscience, 2: $737-738$.

World Bank. 2009. Forests Sourcebook: Practical Guidance for Sustaining Forests in International Cooperation. Washington D.C.: The World Bank

Yesuf, M. and Bluffstone, R. 2009. Poverty, Risk Aversion and Path Dependence in Low Income Countries: Experimental Evidence from Ethiopia. American Journal of Agricultural Economics, 91(4): 1022-1037 